\title{
Credit Risk Management and Financial Performance of Microfinance Institutions in Kampala, Uganda
}

\section{Bashabe Shieler ${ }^{1}$ Kalu O. Emenike ${ }^{2}$ Christian U. Amu}

${ }^{\prime}$ Department of Finance and Accounting, Kampala International University Kampala, Uganda ${ }^{-D e p a r t m e n t ~ o f ~ A c c o u n t i n g ~ a n d ~ F i n a n c e ~ K a m p a l a ~ I n t e r n a t i o n a l ~ U n i v e r s i t y ~ K a m p a l a, ~ U g a n d a ~}$ ${ }^{s}$ Department of Financial Management Technology Federal University of Technology Owerri, Imo State, Nigeria

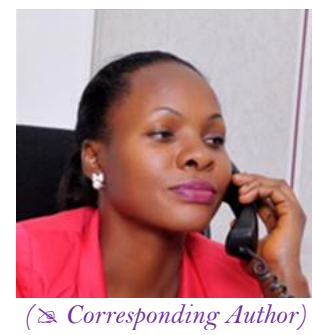

Theck for updates

\begin{abstract}
The objective of this study was to evaluate whether relationship exist between credit risk management techniques and financial performance of microfinance institutions in Kampala, Uganda. Specifically, the study examined whether there is a relationship between credit risk identification, credit risk appraisal, credit risk monitoring, credit risk mitigation and financial performance of microfinance institutions in Kampala using sample of 60 members of staff in finance and credit departments of three licensed microfinance institutions in Kampala, Uganda namely Finca Uganda Ltd, Pride Microfinance Ltd, UGAFODE Microfinance Ltd. Primary data was collected using questionnaires and it comprised of closed ended questions. Secondary data was collected from the microfinance institutions (MDI's) annual reports (2011 - 2015). Frequencies and descriptive statistics were used to analyse the population. Pearson linear correlation coefficient was adopted to examine relationship between credit risk management techniques and financial performance. The findings indicate that credit risk identification and credit risk appraisal has a strong positive relationship on financial performance of MDIs, while credit risk monitoring and credit risk mitigation have moderate significant positive relationship on financial performance of MDIs. The study recommends, among others, that the credit risk appraisal process should identify and analyse all loss exposures, and measure such loss exposures. This should guide in selection of technique or combination of techniques to handle each exposure. The study concludes that MDIs should continually emphasise effective credit risk identification, credit risk appraisal, credit risk monitoring, and credit risk mitigation techniques to enhance maximum financial performance.
\end{abstract}

Keywords: Credit risk management, Credit risk identification, Credit risk appraisal, Credit risk monitoring, Credit risk mitigation, Financial performance, Microfinance institution, Uganda.

JEL Classification: G2 1, G32, N27.

\section{Introduction}

Credit risk, according to Basel (2000) is the potential that a bank borrower or counterparty will fail to meet its obligations in accordance with agreed terms. It is a risk of borrower default, which occurs when counterparty defaults on repayment. The reasons for loan default / loan delinquency are when the obligor is in a financially stressed situation (Gestel and Baesens, 2008). Inadequate financial analysis, inadequate loan support according to Sheila (2011) are the causes of loan default. Credit risk management is the identification, measurement, monitoring and control of risk arising from the possibility of default from loan repayment (Early, 1966; Coyle, 2000). Credit risk management also refers to the systems, procedures and controls, which a company has in place to ensure the efficient collection of customer payments thereby minimising the risk of non-payment (Mokogi, 2003). There are different techniques of credit risk management that this study will focus on; they include credit risk identification, credit risk appraisal, credit risk monitoring and credit risk mitigation.

Numerous countries across the globe have implemented credit risk management in their business operations because of the understanding that risk exists as part of an environment in which various organizations operate (Tchankova, 2002). The concept of credit is old and can be traced back in history. Ditcher (2003) observes that banks in USA gave credit to customers with high interest rate which discouraged borrowing. As a result, the concept of credit did not become popular until the economic boom in USA in 1885 when banks had access to liquidity and wanted to lend excess cash.

In Africa, credit was largely appreciated in the 1950's when most of banks started opening the credit sections and departments to give loans to white settlers. Uganda is one of developing countries in Africa that has recently started to promote microfinance institutions. As a result, non-performing loans is on the increase thus lowering the level performance of microfinance institutions (MDI's). Available statistics from the Bank of Uganda annual 
supervision report, 2015 indicates high incidence of credit risk reflected by increasing non-performing loans (NPLs) by MDI's. The situation has adversely impacted on their profitability and overall asset quality has deteriorated. The NPL ratio (NPLs to total gross loans) increased from 3.2\% in December 2011 to $5.3 \%$ December 2012 it decreased marginally in December 2013 to $3.4 \%$ and again rose to $4.2 \%$ in December 2014 and then rose to $6.6 \%$ in December 2015. This trend not only threatens the viability and sustainability of MDI's but also hinders the goals for which they were intended to achieve that is provision of micro finance services mainly to small and medium enterprises (SME's) (Ministry of Finance Planning and Economic Development (MFPED), 2002). Failure to control credit, could result in insolvency as success of MDI's largely depends on the effectiveness of their credit risk management practices (Alfred, 2011).

There have been a number of studies on credit risk management and financial performance both in developed and developing countries (see for example, (Alshatti, 2015; Otieno et al., 2016)). There is no study, to the researcher's knowledge, that has examined the relationship between credit risk management techniques and financial performance of Micro finance deposit taking institutions in Kampala, Uganda. As a result, this study intends to close the empirical literature gap.

The objective of this study therefore, was to evaluate the relationship between credit risk management techniques and financial performance of microfinance institutions in Kampala, Uganda. Specifically, the study aimed at analysing whether a relationship exist between credit risk identification, credit risk appraisal, credit risk monitoring, credit risk mitigation and financial performance of microfinance institutions in Kampala Uganda. Understanding the relationship between credit risk management techniques and financial performance will benefit microfinance institutions and monetary authorities. Microfinance institutions, for example, will adopt appropriate credit risk management measures to avoid default from a borrower or counterparty to meet its obligations in accordance with agreed terms. Monetary authorities will also benefit through the understanding of effective credit risk management techniques and thus make proactive policies measures to enforce their adoption, thereby control accumulation of non-performing loans. The study will further enrich existing knowledge on relationship between credit risk management techniques and financial performance of microfinance institutions in Africa as well as provide literature for future researchers on related subject. The remainder of this paper organised as follows: Section 2 contains review of empirical literature. Section 3 describes data and methodology. Section 4 presents results ad discussions, and section 5 provides conclusions and recommendations.

\section{Review of Empirical Literature}

Various researches have analysed the linkage between credit risk management and financial performance, and how effective credit risk management contributes to reduction of defaults by counterparty as well as restricting uncertainty of achieving the required financial performance. Otieno et al. (2016) evaluated the relationship between credit risk management and financial performance of microfinance banks in Kenya using Pearson correlation coefficient. The population of the study comprised of 12 licensed microfinance Banks. Longitudinal research design utilising panel data covering the period from 2011 to 2015 was used. The results show that credit risk management with PAR and LLPCR parameters had a strong negative correlation with both ROAA and ROAE performance measure. Thus, the study concludes that credit risk management impacts performance of MFBs. The study recommends that credit managers should operate under a sound credit granting process with well-defined creditgranting criteria detailing the MFB's target market, a thorough understanding of the borrower's purpose and source of repayment.

Justus et al. (2016) assessed the influence of credit risk management practices on loan delinquency in SACCOS in Meru County, Kenya. The study adopted a descriptive research design and the population consisted of all the 44 credit officers of SACCOs in Meru County. Questionnaire was used to collect data. Multiple linear regressions were used in data analysis. Analyzed data was presented in percentages and frequency tables. The study revealed that there exist a strong relationship between credit risk controls, collection policy and loan delinquency in SACCOs. Thus the study concludes that credit risk management practices significantly influenced loan delinquency in SACCOs in Meru County. The study recommends adoption of a more stringent policy on credit risk management practices in SACCOs for effective debt recovery

Kimotho and Gekara (2016) conducted a study on the effect of credit risk management and financial performance of commercial banks in Kenya. The purpose of study was to examine effect of credit risk management practices on financial performance of commercial Bank in Kenya. The study adopted descriptive research design and target population consisted of credit risk managers, credit analyst and debt recovery managers. The study revealed that credit risk management procedures are used to influence profitability of the bank positively and also recommends the management of the banks to oversee facilitation of credit risk management as a substantial degree of standardisation of process and documentation. The study recommended that the bank should consider risk identification as a process in credit risk management and focus on interest risks and foreign exchange risks to great extent in the risk identification map.

Alshatti (2015) examined the effect of credit risk management on financial performance of the Jordanian commercial banks during the period 2005 to 2013. Thirteen commercial banks were chosen to express on the whole Jordanian commercial banks. The research revealed that the credit risk management affects financial performance of the Jordanian commercial banks as measured by ROA and ROE. Based on findings, the researcher recommends amongst others that banks should improve their credit risk management to achieve more profits, banks should take into consideration the indicators of non-performing loans/gross loans, and that banks should establish adequate credit risk management policies by imposing strict credit estimation before granting loans to customers.

Lagat et al. (2013) analysed the effect of credit risk management practices on lending portfolio among savings and credit cooperatives in Kenya using data on risk identification, risk analysis, risk monitoring, risk evaluation and risk mitigation obtained from 59 SACCOs in Nakuru County. The study applied regression models in the analysis, and the results indicate significant effect of all the risk management practices on loan portfolio except risk evaluation which did not register significant effect on the lending portfolio of the SACCOs. The findings further 
showed almost all (99\%) the respondents who participated in the study noted that monitoring was part of their credit management activities and it was influencing their lending portfolio to a great extent. From the findings of the study it was concluded that majority of the SACCOs have adopted largely risk management practices as a means of managing their portfolio.

Moti et al. (2012) examined the effectiveness of credit management system on loan performance of microfinance institutions. Specifically it sought to establish the effect of credit terms, client appraisal, credit risk control measures and credit collection policies on loan performance. The researchers adopted a descriptive research design. The respondents were the credit officers of the MFIs in Meru town. The results show that the credit management system variables have significant impact on loan performance of microfinance institutions. It also reports that collection policy has a higher effect on loan repayment at $5 \%$ significance level. The study recommends that microfinance institutions should consider credit insurance, signing of covenants, credit rating, reports on financial condition, and diversification in granting loans.

Mulondo (2011) investigated the relationship between credit risk management and loan performance of two development finance institutions in Uganda. The study found that loan appraisal showed a very strong significant relationship as compared to other risk management techniques such as risk transfer and risk diversification. The study recommends that considering that there is a significant positive relationship between loan appraisal and loan performance, it is important for the bank to formulate appraisal process/procedures, format that details ways of capturing all the credit risk. The appraisal process should identify and analyze all loss exposures, and measure such loss exposures. The appraisal process should capture key issues like capital adequacy, capacity of applicant, value of collateral, and repayment history.

Mutangili (2011) analysed the relationship between credit risk management practices and the level of nonperforming loans for commercial banks in Kenya. The study documented evidence of negative linkage between the level of non-performing loans and credit risk management practices in banks. He concludes that level of nonperforming loans is inversely related to credit risk management practices. He therefore recommends that commercial banks should adopt various credit risk management practices to reduce the level of non-performing loans. In addition, he further recommends that sustainable and reliable credit database should be established for availability of credit information needed by banks.

Ochola (2009) evaluated the relationship between credit risk management and non- performing loans. The study show that a combination of intensive credit risk management by the banks coupled with close supervision by central bank has greatly enhanced the decline of non-performing loans ratio in the banking sector. Analysing the asset quality of financial sector for 2003 to 2008, the ratio of gross non-performing loans to gross loans declined from a high $35 \%$ in 2003 to a low of 9.23 in 2008. This decline supports evidence of close relationship of nonperforming loans and credit risk management.

\section{Data and Methodology}

The study employed both primary and secondary data. Primary data was obtained through self-administered questionnaires distributed to staff in the three MDI'S especially those with a credit function or with prior experience in the credit function. The questionnaire was selected as an instrument to collect the data because it is straight forward and less time consuming for respondents. The questionnaires were structured and were administered through drop and pick later method and the researcher used e-mails and telephone calls to contact the respondents. The secondary data was obtained by analysing financial statements and annual reports of MDIs for the period of 5 years from year 2011 to 2015.

The target population of the study was 60 members of staff in finance and credit departments from three licensed microfinance institutions in Kampala, Uganda namely Finca Uganda Ltd, Pride Microfinance Ltd, UGAFODE Microfinance Ltd. These respondents were considered for the study because of knowledge and skills they possess in relation to the variables under the study

A census survey method was adopted in this study where the researcher used 60 respondents (credit risk managers, credit officers, Auditors, accountants and debt recovery officers) from the branches of the three licensed microfinance institutions in Kampala, Uganda. Census survey method was used because the target population was manageable and data was collected from the whole population (Singh and Masuku, 2014).

Validity was determined using Content Validity Index (C.V.I). C.V.I= (no of questions declared valid/total no of questions). A CVI of 0.86 was used to declare that the research instrument was valid since it was above 0.7 which is the minimum CVI index required to declare a research instrument valid (Amin, 2005). An instrument is reliable if it produces the same results whenever it is repeatedly used to measure trait or concept from the same respondents even by other researchers (Amin, 2005). Reliability (internal consistency and stability) of the instruments was tested using Cronbach's Alpha Coefficient (Cronbach, 1946). The Cronbach's Alpha coefficient test indicated that the questionnaires where reliable since the coefficient was above $0.5(\alpha=0.74)$.

The secondary data was analysed using Pearson's linear correlation coefficient (PLCC) to determine the nature of relationship between credit risk management and financial performance. The sign (+ or -) indicates the direction of the relationship. The value can range from -1 to +1 , with +1 indicating a perfect positive relationship, $O$ indicating no relationship and -1 indicating a perfect negative or reverse relationship. The PLCC $r$ is specified thus:

$$
r=\frac{n \sum(x y)-\left(\sum x\right)\left(\sum y\right)}{\sqrt{\left[n \sum x^{2}-\left(\sum x\right)^{2}\right] \sqrt{\left[n \sum y^{2}-\left(\sum y\right)^{2}\right.}}}
$$

Where, $\mathrm{r}$ is the correlation coefficient, $\mathrm{n}$ is the number of observations, $\mathrm{x}$ and $\mathrm{y}$ are dependent and independent variables, in this case credit risk management and financial performance. All data was analyzed at $5 \%$ level of significance. Thus if the p-value was less than 0.05 the null hypotheses were rejected. If, on the other hand, the pvalue was greater than 0.05 , the null hypotheses were not rejected. 


\section{Results and Discussions}

\subsection{Analysis of Respondents}

The results that follow show the background characteristics of the respondents that were involved in the study. 60 questionnaires were administered to respondents in three licensed MDI'S in Kampala, Uganda namely Finca Uganda Ltd, Pride Microfinance Ltd and UGAFODE Microfinance Ltd. Overall 60 responded to the questionnaires which represented a response rate of $100 \%$ as reflected in the Table 1 below.

Table-1. Response Rate

\begin{tabular}{l|l|l|l|l}
\hline \multicolumn{2}{l}{} & Frequency & Percent & Cumulative Percent \\
\hline Valid & Finca Uganda Limited & 18 & 30.0 & 30.0 \\
\hline & Pride Microfinance Ltd & 23 & 38.3 & 68.3 \\
\hline & Ugafode microfinance Limited & 19 & 31.7 & 100.0 \\
\hline & Total & $\mathbf{6 0}$ & $\mathbf{1 0 0 . 0}$ & \\
\hline
\end{tabular}

According to the results in the Table 1 above, the greatest number of respondents were from Pride Microfinance Ltd (23 respondents) representing 38.3\% of the total number of respondents followed by Ugafode Uganda Ltd (19 respondents) representing 31.7\% and Finca Uganda Limited (18 respondents) representing 30.0\%.

Table-2. Respondent demographic characteristics

\begin{tabular}{l|l|l}
\hline Gender & Frequency & Percentage \\
\hline Male & 33 & 55.0 \\
\hline Female & 27 & 45.0 \\
\hline Total & 60 & 100 \\
\hline Source: primary data 2016 &
\end{tabular}

According to the findings presented in Table 2 above the researcher established that majority of the respondents were male as shown by $55.0 \%$ whereas $45.0 \%$ of the respondents were female, this shows that both male and females were well represented in this study and thus the finding of the study did not suffer from gender bias

Table-3. Age of the respondents

\begin{tabular}{|c|c|c|}
\hline Age & Frequency & Percentage \\
\hline 20-30 years & 24 & 40.0 \\
\hline $31-40$ years & 30 & 50.0 \\
\hline $41-50$ years & 6 & 10.0 \\
\hline Total & 60 & 100 \\
\hline
\end{tabular}

The study requested the respondents to indicate their age category, from the findings as shown in Table 3 above the study established that majority of the respondents as shown by $50.0 \%$ were aged between 31 to 40 years. This could imply that this is the most active and mobile age group which a microfinance institution can use in the supervision and monitoring of its volatile loan portfolio. $40.0 \%$ of the respondents were aged between 20 to 30 years and the remaining $10 \%$ of the respondents were aged between 41 to 50 years. This is an indication that respondents were well distributed in terms of age.

Table-4. Highest Education level Achieved

\begin{tabular}{l|l|l}
\hline Education level & Frequency & Percentage \\
\hline Diploma & 4 & 6.7 \\
\hline Degree & 47 & 78.3 \\
\hline Master's Degree & 8 & 13.3 \\
\hline$>=$ PHD & 1 & 1.7 \\
\hline Total & 60 & 100 \\
\hline Source: primary data 2016 &
\end{tabular}

The study requested respondents to indicate their highest education level, from the findings in Table 4 above, $78.3 \%$ of the respondents are bachelor degree holders, $13.3 \%$ of the respondents indicated their highest education level as master degree, whereas $6.7 \%$ of the respondents are diploma holders, and $1.7 \%$ of the respondents indicated their highest education level as $\mathrm{PhD}$. This is an indication that majority of the employee engaged in this research had university degree certificates as their highest level of education.

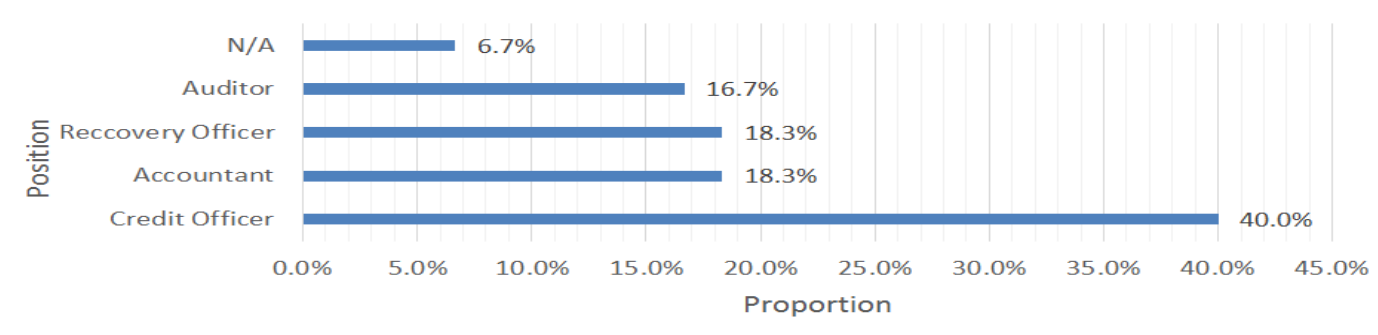


The study sought to determine the current rank of respondents within organization. From the research findings, the study showed that majority of the respondents as shown by $40.0 \%$ indicated to be the credit officers, $18.3 \%$ of the respondents indicated to be the recovery officers likewise $18.3 \%$ of the respondents indicated to be the accountants, $16.7 \%$ of the respondents indicated to be the auditors and the remaining $6.7 \%$ of the respondents indicated no answer. This indicates that majority of the respondents are credit officers.

Table-5. Previous Working Knowledge from Credit

\begin{tabular}{l|l|l}
\hline & Frequency & Percentage \\
\hline Yes & 56 & 93.3 \\
\hline No & 04 & 6.7 \\
\hline Total & 60 & 100.0 \\
\hline Source: primary data 2016 &
\end{tabular}

From Table 5 above, about $93.3 \%$ of the respondents have prior experience of working in the credit section and $6.7 \%$ has no prior experience in credit department. This indicates that majority of the respondents have prior experience working in the credit section.

Table-6. Working experience in the banking sector.

\begin{tabular}{l|l|l}
\multicolumn{2}{c}{ Table-6. Working experience in the banking sector. } \\
\hline & Frequency & Percentage \\
\hline$<2$ years & 3 & 5.0 \\
\hline $2-5$ years & 43 & 71.7 \\
\hline $6-10$ years & 14 & 23.3 \\
\hline Total & 60 & 100.0 \\
\hline Source: primary data 2016 &
\end{tabular}

The results in the Table 6 above indicate that $71.7 \%$ of respondents had working experience in banking sector of 2 to 5 years, $23.3 \%$ of respondents had working experience in banking sector of 6 to 10 years and 5 . $0 \%$ of respondents had working experience in banking sector of less than 2 years. This indicates that majority of the respondents had working experience in banking sector of 2 to 5 years.

\subsection{Correlation Analysis}

Pearson linear correlation coefficient (PLCC) was used to establish relationship between the variables considered in the model thus; return on equity, credit risk identification, credit risk appraisal, credit risk monitoring and credit risk mitigation. The results of PLCC are presented in Table 7 below.

Table-7. Pearson linear correlation coefficient

\begin{tabular}{|c|c|c|c|c|c|c|}
\hline & & ROE & CRI & CRA & CRM & CRMI \\
\hline \multirow[t]{2}{*}{$\mathrm{ROE}$} & Correlation Coefficient & 1.000 & & & & \\
\hline & Sig. (2-tailed) & & & & & \\
\hline \multirow[t]{2}{*}{ CRI } & Correlation Coefficient & $.647(*)$ & 1.000 & & & \\
\hline & Sig. (2-tailed) & .033 & & & & \\
\hline \multirow[t]{2}{*}{ CRA } & Correlation Coefficient & 659 (**) & 281 & 1.000 & & \\
\hline & Sig. (2-tailed) & .008 & .236 & 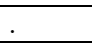 & & \\
\hline \multirow[t]{2}{*}{ CRM } & Correlation Coefficient & $.514(*)$ & $.764(* *)$ & .477 & 1.000 & \\
\hline & Sig. (2-tailed) & .017 & .002 & .067 & . & \\
\hline \multirow[t]{2}{*}{ CRMI } & Correlation Coefficient & $508(*)$ & 315 & .176 & $.662(*)$ & 1.000 \\
\hline & Sig. (2-tailed) & .011 & .227 & .177 & .043 & . \\
\hline
\end{tabular}

As presented in Table 7 above, p- value $=0.033<0.05$ and because the p-value $(0.033)$ is less than the significance level (0.05), the null hypothesis is rejected. This implies that a strong significant positive relationship exist between credit risk identification and financial performance. This finding is in line with the study of Kimotho and Gekara (2016) who noted that there was positive association between credit risk identification and financial performance of commercial banks in Kenya. This is also consistent with the view of Fuser et al. (1999) who asserted that risk identification process includes risk-ranking components and that they help in sorting risk according to their importance and assists the management to develop risk management strategy to allocate resources efficiently and therefore improving their credit performance.

The computed correlation coefficient is 0.659 and p- value $=0.008<0.05$ and because the p-value $(0.008)$ is less than the significance level of (0.05), the null hypothesis is rejected. This implies that there exists a strong significant positive relationship between credit risk appraisal and financial performance. This study finding concurs with the finding of Kimotho and Gekara (2016) whose study revealed that there was a positive effect between credit appraisal analysis and financial performance of commercial banks in Kenya. He added that commercial banks used credit appraisal analysis to a great extent. Kurui and Aquilars (2012) in their study also revealed a positive association between client appraisal and loan performance in MFIs in Baringo County. Mulondo (2011) also document evidence to show that loan appraisal has a very strong significant relationship as compared to other risk management techniques like risk transfer and risk diversification.

The computed correlation coefficient is 0.514 and $p$ - value $=0.017<0.05$ and because the p-value $(0.017)$ is less than the significance level of (0.05), the null hypothesis is rejected. The researcher revealed that there exists a moderate significant positive relationship between credit risk monitoring and financial performance. This implies that monitoring reports should be frequent, timely, accurate and informative and should be distributed to appropriate individuals to ensure action. The study is in line with literature of IRM et al. (2002) that an effective risk monitoring requires reporting and review structure to ensure that risks are effectively identified and assessed and that appropriate controls and responses are in place. 
The computed correlation coefficient is 0.508 and p- value $=0.011<0.05$ and because the p-value $(0.011)$ is less than the significance level of (0.05), the null hypothesis is rejected. This implies that there exists a moderate significant positive relationship between credit risk mitigation and financial performance which concurs with the work of Brannan (2000) who argued that diversification, is the primary tool for lenders to control borrower risk and realize financial performance. The findings also concur with the study of Wilson (1998) who advocates for diversification of loan portfolio across nations where the benefits are much stronger than they are when diversification occurs across sectors in a given economy. The study of Justus et al. (2016) also show that a significant relationship exist between credit risk control and loan delinquency in SACCOS in Meru County, Kenya. The findings of study are also in line with the study of Moti et al. (2012) who documented that credit insurance, signing covenants with customers, diversification of loans and credit rating of customers had a positive effect on loan performance.

\section{Conclusions and Recommendations}

From the findings of the study, we observe that majority of respondents in this study ranged between 31-40 years $(45.1 \%)$ and majority of respondents were male (55.0\%) and these respondents had attained bachelors' degree as their highest academic qualification (78.3\%), majority of respondents had working experience in the banking sector of 2-5 years (71.7\%). We therefore conclude that credit risk identification, credit risk appraisal, credit risk monitoring, and credit risk mitigation are strong variables in determining financial performance of MDIs in Kampala, Uganda.

Consequently, we recommend that credit risk identification should not be a one off thing as some risks could be hard to detect or overlooked by those tasked to identify them and therefore it should be a continuous process which is carried out at different places and by different individuals. It is important for the MDI's to formulate an appraisal process/ procedures, format that details ways of capturing all the credit risk. The appraisal process should identify and analyze all loss exposures, and measure such loss exposures. This should guide in selection of technique or combination of techniques to handle each exposure. The appraisal process should capture key issues like the capitalisation of the business, capacity of the applicant, value of the collateral, and repayment history and conditions that is economical, political before a project is financed. We also recommend that MDI's should enhance their credit risk monitoring techniques so as to improve their financial performance. With through credit risk monitoring techniques, the MDI's will be able to know the credit score of their clients and also help the MDI's management to discover mistakes at an early stage thus take necessary steps to reduce their non-performing loans. This will also prevent diversion and misapplication of funds which are indentified as important causes of nonperforming loans in MDIs. There is also need for MDIs to enhance their credit risk mitigation this will help in decreasing default levels as well as their non-performing loans. This will help in improving their financial performance. There is also need for MDIs to increase use of insurance firms in a bid to transfer or share risk in case of default. This may help in decreasing loan default levels and improving their financial performance

\section{References}

Alfred, O., 2011. Corporate governance and financial performance of SACCOs in Lango sub region. Un Published Master's Thesis, Makerere University.

Alshatti, A.S., 2015. The effect of credit risk management on financial performance of the Jordanian commercial banks. Investment Management and Financial Innovations, 12(1): 338-339.

Amin, M.E., 2005. Social science research, conception, methodology and analysis. Kampala: Makerere University Printery.

Basel, 2000. Principles for the management of credit risk. Consultative Paper Issued by the Basel Committee on Banking Supervision.

Brannan, S., 2000. The quantification and trading of credit risk. Wharton financial institutions center financial engineering roundtable, May 5. Retrieved from http://www.frbsf.org/economic-research/files/lopez-whartonoo.pdf.

Coyle, B., 2000. Framework for credit risk management: Chartered institute of bankers, United Kingdom.

Cronbach, L.J., 1946. Response sets and tests validating. Journal for Educational \& Psychological Measurement, 6(4): $475-494$.

Ditcher, B., 2003. Corporate finance and investment. Decisions and strategies. England: Prentice Hall.

Early, J.S., 1966. Problems in the measurement of the quality of credit. Proceedings of the Business and Economic Statistics Section of the American Association. pp: 202-217.

Fuser, K., W. Gleiner and G. Meier, 1999. Risk management. Erfahrungen aus der Praxis, Der Betrieb, 52(15): 753-758.

Gestel, T.V. and B. Baesens, 2008. Credit risk management basic concepts: Financial risk components, rating analysis, models, economic and regulatory capital. Oxford University Press.

IRM, AIRMIC and ALARM, 2002. A risk management standard, the institute of risk management. The national forum for risk management in the public sector. London, UK: The Association of Insurance and Risk Managers.

Justus, N.M., K.K. Dickson and M.M. Harrison, 2016. Influence of credit risk management practices on loan delinquency in savings and credit cooperative societies in Meru County, Kenya. International Journal of Economics, Commerce and Management, 4(2): 763773 .

Kimotho, D.N. and M. Gekara, 2016. Effects of credit risk management practices on financial performance of commercial banks in Kenya. International Journal of Economics \& Finance, 2(3): 116-189.

Kurui, S.K. and M.K. Aquilars, 2012. Influence of credit risk management practices on loan performance of microfinance institutions in Baringo County. International Journal of Science and Research, 3(10): 2319-7064.

Lagat, F.K., R. Mugo and R. Otuya, 2013. Effect of credit risk management practices on lending portfolio among savings and credit cooperatives in Kenya. European Journal of Business and Management, 5(19): 2222-2839.

Ministry of Finance Planning and Economic Development (MFPED), 2002. Uganda Poverty Reduction Strategy Paper Progress Report 2002. Retrieved from https://www.imf.org/External/NP/prsp/2002/uga/01/033102.pdf.

Mokogi, J.G.O., 2003. Economic implications of lending of Micro finance institution on MSES. Unpublished MBA Project, University of Nairobi.

Moti, H.O., J.S. Masinde, N.G. Mugenda and M.N. Sindani, 2012. Effectiveness of credit management system on loan performance. Empirical evidence from microfinance sector in Kenya. International Journal of Business, Humanities and Technology, 2(6): 99-108.

Mulondo, R., 2011. Credit risk management and loan performance in development financing. MBA Thesis. Makerere University Business School. Makerere University. Retrieved from https://studylib.net/doc/8046637/.

Mutangili, O.M., 2011. The relationship between credit risk management practices and the level of nonperforming loans for commercial banks in Kenya. Unpublished MBA Thesis, University of Nairobi.

Ochola, J.O.E., 2009. A study of the relationship between credit risk management and non-performing loans. Unpublished MBA Project, University of Nairobi.

Otieno, S., M. Nyagol and A. Onditi, 2016. Relationship between credit risk management and financial performance. Empirical evidence from microfinance banks in Kenya. Research Journal of Finance and Accounting, 7(6): 2222-2847. 
Sheila, A.L., 2011. Lending methodologies and loan losses and default in a microfinance deposit-taking institution in Uganda. A case study of
Finca
Uganda
Kabala
Branch
(MDI).
Retrieved
from

Singh, A.S. and M.B. Masuku, 2014. Sampling techniques \& determination of sample size in applied statistics research. International Journal of Economics, Commerce and Management, 2(11): 10-11.

Tchankova, V.M.R., 2002. Applying a risk management process to manage cost risk for EHV transmission line project. International Journal of Project Management, 17(4): 223-235.

Wilson, T.C., 1998. Portfolio credit risk. Economic Policy Review, 4(3): 71-82.

Citation | Bashabe Shieler; Kalu O. Emenike; Christian U. Amu (2017). Credit Risk Management and Financial Performance of Microfinance Institutions in Kampala, Uganda. Journal of Banking and Financial Dynamics, 1: 29-35.

History:

Received: 27 March 2017

Revised: 25 April 2017

Accepted: 4. May 2017

Accepted: 4 May 2017

Licensed: This work is licensed under a Creative Commons

Attribution 3.0 License (cc))

Publisher: Eastern Centre of Science and Education
Acknowledgement: All authors contributed to the conception and design of the study.

Funding: This study received no specific financial support.

Competing Interests: The authors declare that they have no conflict of interests.

Transparency: The authors confirm that the manuscript is an honest, accurate, and transparent account of the study was reported; that no vital features of the study have been omitted; and that any discrepancies from the features of the study have been omitted
study as planned have been explained.

Ethical: This study follows all ethical practices during writing.

Eastern Centre of Science and Education is not responsible or answerable for any loss, damage or liability, etc. caused in relation to/arising out of the use of the content. Any queries should be directed to the corresponding author of the article. 